\title{
Simulation of Groundwater Quality Characteristics using Artificial Neural Network
}

\author{
O. O. Fadipe ${ }^{\text {a,* }}$, L. K. Abidoye ${ }^{\text {b }}$, J. O. Adeosun ${ }^{\mathrm{c}}$, B. B. Oguntola ${ }^{\mathrm{d}}$, O. Adewusi ${ }^{\mathrm{e}}$, \\ T. E. Okeowo ${ }^{f}$ \\ ${ }^{a}$ Civil Engineering Department, Osun State University, Osogbo, Osun State, NIGERIA. \\ ${ }^{b}$ Chemical Engineering Department, Osun State University, Osogbo, Osun State, NIGERIA. \\ ${ }^{c}$ Building Engineering Department, Osun State University, Osogbo, Osun State, NIGERIA. \\ ${ }^{d}$ Directorate of Works and Physical Planning, Redeemer University, Ede, Osun State, NIGERIA. \\ ${ }^{e}$ Osun State Ministry of Water Resources, Osogbo, Osun State, NIGERIA. \\ fOsun State Ministry of Works, Osogbo, Osun State, NIGERIA.
}

\begin{abstract}
This paper reports the study of groundwater quality assessment in Boluwaduro community, Ofatedo in Osun State. In addition, it utilized the Artificial Neural Network (ANN) tool in MATLAB Software to simulate the water quality parameters / contaminants. Water samples were taken from 18 randomly selected dugwells and subjected to physico-chemicals and microbiological analysis. The mean concentrations of nitrate, nitrite, lead and iron are $20.12 \mathrm{mg} / \mathrm{L}, 0.78 \mathrm{mg} / \mathrm{L}, 0.159 \mathrm{mg} / \mathrm{L}$ and $0.35 \mathrm{mg} / \mathrm{L}$ respectively. Total plate counts range between $27-96 \mathrm{cfu} / \mathrm{mL}$ with growth in all the water samples. The ANN structure was trained in several rounds till satisfactory output was obtained with correlation value of $R^{2}=0.97$. Simulation of the $p H$ using ANN provides a good match at $10 \%$ increment of chloride, nitrate and iron and the $\mathrm{pH}$ value of the water sources increased with the corresponding increase in the concentrations of the parameters. The generated model for TDS gave a good prediction with total hardness and magnesium respectively. The concentrations of some metals in the wells are not safe for drinking; it could pose danger to users of the water sources. It is therefore recommended that the wells in the community should be subjected to routine monitoring and treatment of the contaminants should be enforced.
\end{abstract}

Keywords: water quality, dug wells, ANN, physico-chemical characteristics, microbiological characteristics

\section{INTRODUCTION}

Groundwater is a viable source of drinking water and its use in augmenting inconsistent pipeborne water in Osun State is high. It has played a fundamental but often unappreciated role in the social well-being of most communities [1]. In most cases, it is used without treatment as it is believed that the ground has natural filtration capacity and mechanisms for removal of particulate matter, dissolved chemicals and gases. Groundwater is prone to pollution from human activities because water is an excellent solvent and since it has a lot of opportunity to dissolve substances as it moves through rocks and subsurface soil, it can contain lots of dissolved chemicals. The quality of groundwater sources is affected by the character-

${ }^{*}$ Corresponding author (Tel: +234 (0)803 453 9764)

Email addresses: olayemifadipe@yahoo.com (O. O. Fadipe), kluqman2002@yahoo.co.uk (L. K. Abidoye), julianah.adeosun@uniosun.edu.ng (J. O. Adeosun), oguntolab@run.edu.ng (B. B. Oguntola), oyebolaadewusi@gmail.com (O. Adewusi), titilayookeowo8@gmail.com (T. E. Okeowo) istics of the media through which the water passes on its way to groundwater zone of saturation [2].

The composition of groundwater is used to determine its potability and serves as a tool for determining the sources of naturally occurring and human related contaminants. Groundwater contains seven major chemical element ions such as Calcium (Ca), Magnesium (Mg), Chloride (Cl), Bicarbonate $\left(\mathrm{HCO}_{3}\right)$, sodium $(\mathrm{Na})$, potassium $(\mathrm{K})$, sulphate $\left(\mathrm{SO}_{4}\right)$ and these play a significant role in classifying and assessing the groundwater quality. Potable water is one that can be used for drinking purposes with safety and satisfaction [3]. Potable or water of good quality is of vital concern to mankind since it is directly linked with human welfare [4]. It has been reported that the most common groundwater-quality problem in rural water supplies is bacterial contamination from septic tanks, which are often used in rural areas that do not have a sewage-treatment system. The occurrence and percentage distribution of the microbial characteristics is very high in wells around a dumpsite suggesting contamination from the leachate [5]. As groundwater flows 


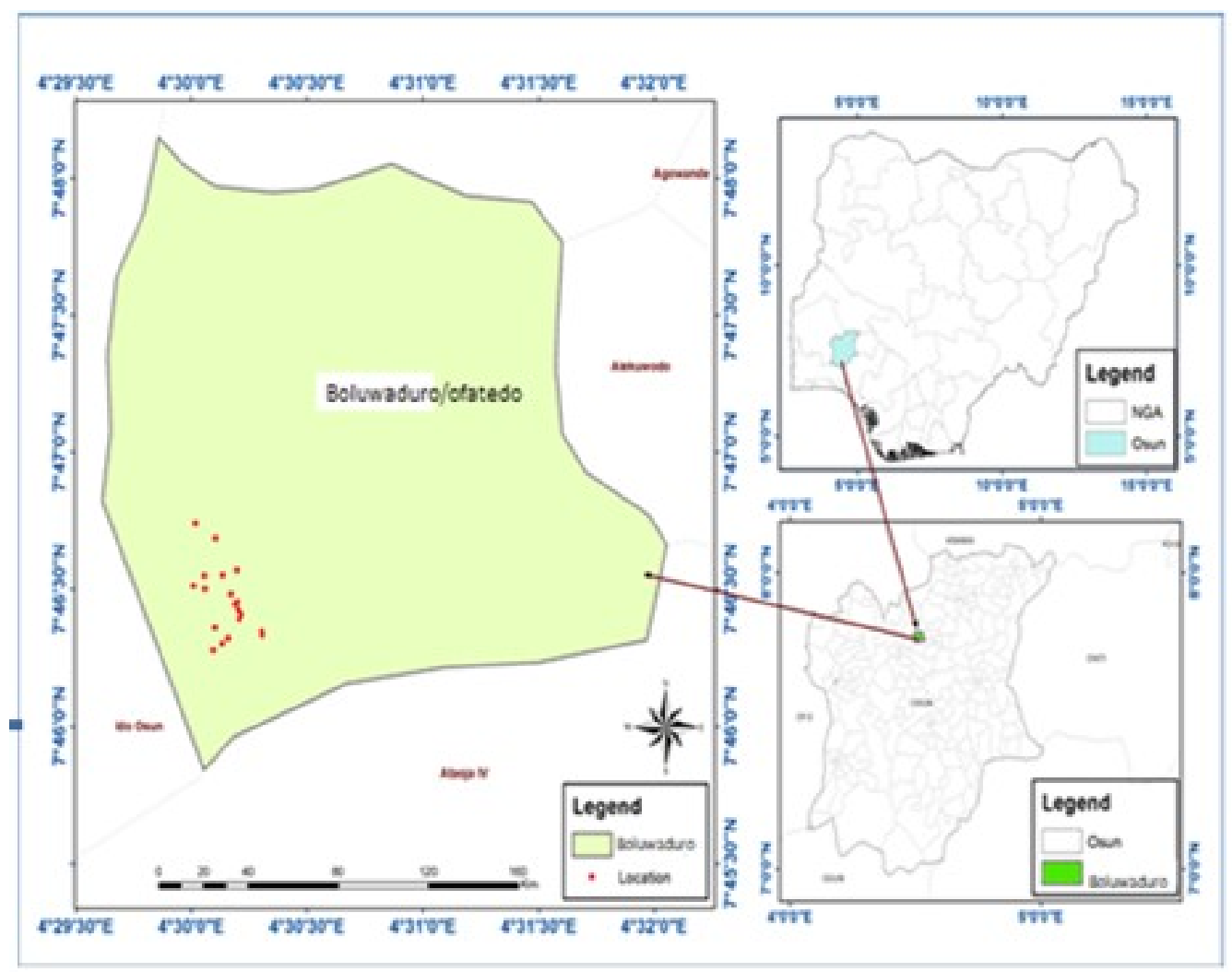

Figure 1: Study Area Map with Sampling Points.

through sediments, heavy metals such as iron, manganese, arsenic, lead etc are dissolved and may later be found in high concentrations in water. The main factors that make groundwater vulnerable as analysed by [6] revealed that soil characteristics and filtration capacity promote or hinder the diffusion of environmental contaminants. The chemistry of groundwater is controlled by the type of geological materials through which the water flows and the amount of time the water is in contact with these materials. Urbanization affects the quantity and quality of groundwater [7] by radically changing the pattern and rates of recharge initiating new abstraction regimes, and advently affecting groundwater quality.

Chemical contamination of drinking water may have effects on health, although in general, these tend to be chronic rather than acute, unless a specific pollution event has occurred and are therefore generally considered of lower priority than microbiological contamination [8]. Potable water helps to decrease mortality and morbidity rate in women, children and infants.

Assessing groundwater quality is very crucial for maintenance and sustainability of the source. A lot of statistical tools have been employed for water quality assessment such as Geographical Information System (GIS), Groundwater Quality Index (GQI), DRASTIC [9], Multivariate analysis (principal component, cluster analysis) [5], Water Quality Index (WQI) [10]. However, when there is a complex non- linear relationship and uncertainty between the parameters of ground wa- ter quality, Artificial Neural Network (ANN) has become a popular method in prediction because they can overcome some of the difficulties associated with traditional statistical approaches. ANN model is a conceptual model and it is a simplified image of the mathematical model. Unlike physically based numerical models, ANNs do not require explicit characterization and quantification of physical properties and conditions of the system under investigation. ANN learns the systems behaviour from representative data. The key advantages of ANN are that it has the ability to learn and model non-linear and complex relationships, which are really important because in real-life, many of the relationships between inputs and outputs are non-linear as well as complex. Groundwater assessment should be conducted on routine basis because factors contributing to quality are time dependent on several factors. Using instrumentation in analysis is most times subjected to errors and titrimetric procedures take longer, hence simulating some parameters could give a quick response. Potable water supply to the study area is irregular, thus residents use dugwells to augment drinking water. This paper presents the result of groundwater quality for potability assessment and also simulates some parameters which are useful for predicting the quality of the dugwells in response to changes in concentrations. 
Table 1: Coordinates of well points.

\begin{tabular}{lllll}
\hline Well No & Easting $(\mathbf{m})$ & Northing $(\mathbf{m})$ & Elevation $(\mathbf{m})$ & Apparent colour \\
\hline 1 & 4.503595 & 7.773480 & 294.40 & Colourless \\
2 & 4.503371 & 7.773716 & 292.40 & Colourless \\
3 & 4.503455 & 7.772210 & 291.80 & Colourless \\
4 & 4.449849 & 7.779220 & 308.00 & Colourless \\
5 & 4.503340 & 7.774218 & 310.60 & Colourless \\
6 & 4.503150 & 7.774096 & 296.78 & Light brown \\
7 & 4.502846 & 7.774693 & 289.40 & Colourless \\
8 & 4.503268 & 7.776145 & 302.90 & Colourless \\
9 & 4.502271 & 7.775845 & 301.60 & Colourless \\
10 & 4.501720 & 7.778095 & 308.90 & Colourless \\
11 & 4.501685 & 7.772680 & 303.70 & Colourless \\
12 & 4.501001 & 7.775025 & 303.50 & Colourless \\
13 & 4.500946 & 7.775821 & 304.80 & Colourless \\
14 & 4.500146 & 7.775211 & 304.80 & Colourless \\
15 & 4.500277 & 7.778988 & 284.90 & Colourless \\
16 & 4.505092 & 7.772203 & 302.60 & Colourless \\
17 & 4.505081 & 7.772403 & 304.00 & Colourless \\
18 & 4.502630 & 7.772028 & 305.20 & \\
\hline
\end{tabular}

Table 2: Descriptive Statistics of Physical Parameters.

\begin{tabular}{llllllll}
\hline Parameters N = 36 & Min & Max & Mean & Std dev & Kurtosis & skewness & WHO \\
\hline Turbidity & 1.130 & 7.41 & 2.85 & 1.36 & 3.54 & 1.70 & 5.0 NTU \\
Temperature & 26 & 28.5 & 27.0 & 0.61 & 0.11 & 0.55 & 26 \\
EC & 143 & 424 & 264.83 & 76.22 & 0.56 & 0.37 & 1000 \\
Ph & 6.55 & 7.71 & 6.94 & 0.24 & 2.16 & 0.89 & $6.5-85$ \\
TDS & 94 & 281.3 & 171.39 & 44.65 & 0.03 & 0.48 & 500 \\
\hline
\end{tabular}

\section{METHODOLOGY}

\subsection{Study Area}

The study area (Fig. 1) is Boluwaduro Community, Ofatedo Area in Egbedore Local Government, Osogbo, Osun State, located along coordinates $7^{\circ} 46^{\circ} 00^{\prime \prime} \mathrm{N}$ and $4^{\circ} 29^{\prime} 30^{\prime \prime} \mathrm{E}$ to $7^{\circ} 48^{\prime} 00^{\prime \prime} \mathrm{N}$ and $4^{\circ} 32 ’ 00 ” \mathrm{E}$.

\subsection{Sampling Points}

A total number of eighteen randomly selected dugwells wells (Table 1) within Boluwaduro community were used for the assessment. A GPS device was used to take the coordinates and it was imported into the study area map using ArcGIS 10.1. Before sampling commenced, the depth of each of the wells and the depth to water levels were measured. Water sampling was carried out twice to cover the rainy and dry season. The water samples were collected in prewashed $1 \mathrm{~L}$ white kegs and were labeled accordingly.

They were transported to the laboratory in ice packs and were analysed within 24 hrs. Physical parameters such as turbidity, temperature, colour, TDS, conductivity, and dissolved oxygen were analyzed using hand held meters on-site and laboratory meters for verification. Chemical and heavy metal characteristics (total alkalinity (TA), total hardness(TH), $\mathrm{Mg}, \mathrm{SO}_{4}, \mathrm{NO}_{3}-\mathrm{N}, \mathrm{NO}_{2}, \mathrm{Cl}$, $\mathrm{HCO}_{3}, \mathrm{CO}_{3}, \mathrm{Fe}, \mathrm{Cr}, \mathrm{Mn}, \mathrm{Pb}, \mathrm{Zn}, \mathrm{Cu}$ and $\mathrm{As}$ ) were analyzed using a combination of titrimetric and instrumentation (Palintest Photometer 5000) at the water laboratory of Osun State Water Corporation. The multiple tube fermentation technique was used for the microbiological analysis

\subsection{Statistics and ANN Modeling}

The results of the analysis were subjected to descriptive statistics and ANN modeling and simulation. The ANN tool of the MATLAB software was used to model the input to output relations. The modeling technique entails different configuration that was chosen and trained till the desired outputs became satisfactory.

\section{RESULTS AND DISCUSSION}

\subsection{Descriptive Statistics}

The physical analysis (Tables 2 ) showed that the results compared well with the WHO standards except for well no 6 (Table 1) that has turbidity value of $7.41 \mathrm{NTU}$ as against 5 NTU permissible values. Often, turbidity is associated with groundwater when small particles are suspended in the water and it scatters and absorbs light rays: this gives the water a murky or turbid appearance. Clay, silt, tiny fragments of organic matter and microscopic organisms are some of the substances that can cause turbidity and they occur in water naturally or because of human activities and pollution. Turbidity is very important in drinking water quality because suspended particles can provide hiding place for harmful microorganism; there by shielding them from disinfection process in a water treatment. 
Table 3: Descriptive Statistics of Physical Parameters.

\begin{tabular}{llllllll}
\hline Parameters (mg/L) & Min & Max & Mean & Std Error & Kurtosis & Skewness & WHO \\
TA & 104.100 & 312.00 & 194.170 & 53.470 & -0.270 & 0.480 & 200.00 \\
$\mathrm{DO}$ & 1.560 & 4.520 & 3.040 & 0.780 & -0.870 & -0.020 & 4.000 \\
$\mathrm{TH}$ & 96.000 & 268.000 & 189.506 & 38.070 & 0.300 & 0.030 & 100.000 \\
$\mathrm{Mg}$ & 1.500 & 30.500 & 14.700 & 6.620 & 0.160 & 0.120 & 10.000 \\
$\mathrm{NO}_{3}-\mathrm{N}$ & 10.000 & 55.500 & 18.620 & 9.040 & 9.050 & 2.870 & 10.000 \\
$\mathrm{SO}_{4}$ & 20.000 & 34.000 & 25.770 & 4.520 & -1.410 & 0.280 & 250.000 \\
$\mathrm{Cl}$ & 3.500 & 46.510 & 16.360 & 9.310 & 2.220 & 1.330 & 250.000 \\
$\mathrm{NO} 2-\mathrm{N}$ & 0.070 & 2.100 & 0.770 & 0.330 & 7.210 & 1.660 & 0.100 \\
$\mathrm{HCO} 3$ & 24.000 & 122.500 & 69.900 & 33.210 & -1.390 & 0.120 & 1.000 \\
$\mathrm{CO} 3$ & 94.000 & 346.000 & 195.000 & 61.560 & -.010 & 0.790 & 0.100 \\
\hline
\end{tabular}

Table 4: Descriptive Statistics of Heavy Metals.

\begin{tabular}{llllllll}
\hline Parameters & Min & Max & Mean & Std Error & Kurtosis & Skewness & WHO \\
$\mathrm{Fe}$ & 0.045 & 2.190 & 0.680 & 36.440 & 35.990 & 5.990 & 0.300 \\
$\mathrm{Cu}$ & 0.000 & 0.880 & 0.110 & 0.250 & 3.550 & 2.210 & 10.00 \\
$\mathrm{Mn}$ & 0.000 & 0.0040 & 0.0010 & 0.001 & 0.070 & 0.990 & 0.200 \\
$\mathrm{Zn}$ & 0.000 & 0.440 & 0.020 & 0.070 & 31.510 & 5.480 & 5.000 \\
$\mathrm{~Pb}$ & 0.000 & 0.021 & 0.010 & 0.010 & -0.970 & 0.570 & 0.010 \\
$\mathrm{Cr}$ & 0.000 & 0.020 & 0.0030 & 0.004 & 2.330 & 1.650 & 0.050 \\
\hline
\end{tabular}

Table 5: Results of Microbiological analysis.

\begin{tabular}{lccccccc}
\hline No of wells & $\begin{array}{c}\text { Total plate } \\
\text { count cfu/ml }\end{array}$ & $\begin{array}{c}\text { Total coliform } \\
\text { MPN/ml }\end{array}$ & $\begin{array}{c}\text { E.coli } \\
\text { cfu/ml }\end{array}$ & No of wells & $\begin{array}{c}\text { Total plate } \\
\text { count cfu/ml }\end{array}$ & $\begin{array}{c}\text { Total coliform } \\
\text { MPN/ml }\end{array}$ & $\begin{array}{c}\text { E.coli } \\
\text { cfu/ml }\end{array}$ \\
\hline 1 & 58 & 3 & Growth & 1 & 76 & 3 & Growth \\
2 & 62 & 8 & Growth & 2 & 45 & 8 & Growth \\
3 & 84 & 4 & Growth & 3 & 92 & 4 & Growth \\
4 & 96 & 7 & Growth & 4 & 84 & 7 & Growth \\
5 & 27 & 5 & Growth & 5 & 32 & 3 & Growth \\
6 & 75 & 4 & Growth & 6 & 82 & 6 & Growth \\
7 & 46 & 16 & Growth & 7 & 44 & 13 & Growth \\
8 & 64 & 4 & Growth & 8 & 62 & 10 & Growth \\
9 & 56 & 11 & Growth & 9 & 60 & 10 & Growth \\
10 & 54 & 6 & Growth & 10 & 52 & 8 & Growth \\
11 & 63 & 6 & Growth & 11 & 60 & Growth \\
12 & 54 & 12 & Growth & 12 & 52 & 11 & Growth \\
13 & 76 & 14 & Growth & 13 & 78 & 15 & Growth \\
14 & 85 & 16 & Growth & 14 & 82 & 12 & Growth \\
15 & 64 & 7 & Growth & 15 & 60 & 8 & Growth \\
16 & 72 & 5 & Growth & 16 & 70 & 8 & Growth \\
17 & 56 & 4 & Growth & 17 & 59 & 3 & Growth \\
18 & 48 & 2 & Growth & & 52 & 6 & Growth \\
\hline
\end{tabular}

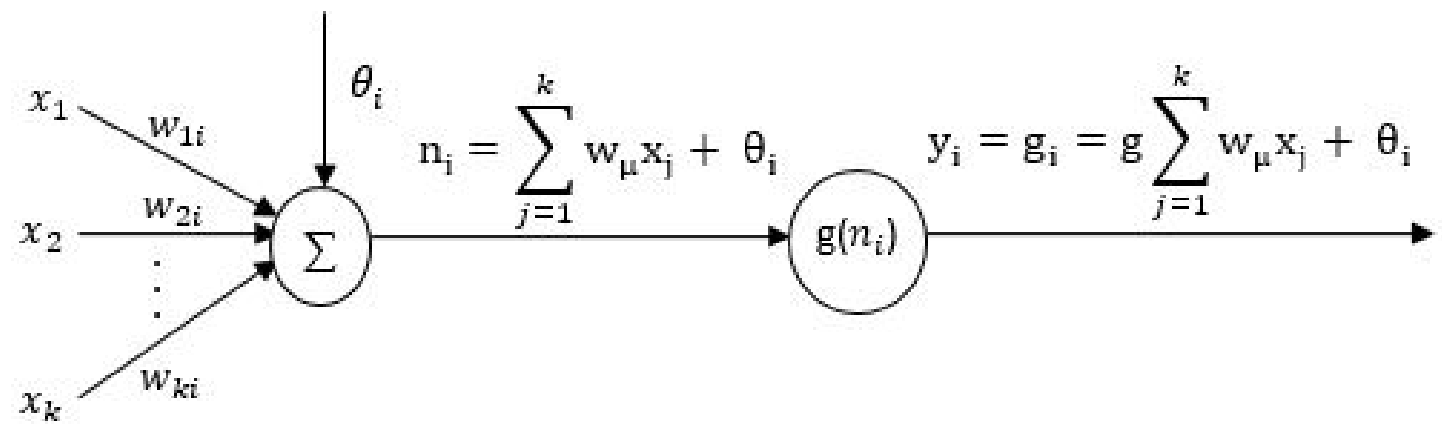

Figure 2: Typical Operation Around a Single Neuron in MLP Network. 
Drinking water that is not adequately disinfected can cause diseases in humans [11]. The temperatures of some of the water samples were higher than the WHO standards. Water with high temperature can lower the solubility of oxygen dissolved in it making such water to taste flat. The chemical characteristics and the heavy metals (Tables 3 and 4) revealed that all the parameters were within $\mathrm{WHO}$ standards except $\mathrm{NO}_{3}$ $\mathrm{N}, \mathrm{NO}_{2}-\mathrm{N}, \mathrm{Fe}$ and $\mathrm{Pb}$. All the wells have nitrates values that were higher than the permissible; the mean and the maximum values (18.62 $\mathrm{mg} / \mathrm{L}, 55.5 \mathrm{mg} / \mathrm{L}$ ) of $\mathrm{NO}_{3}-\mathrm{N}$ were too high and consumers of water of these wells are at risk of nitrate induced symptoms.

The sources of high concentrations of nitrate are mostly anthropogenic, particularly indiscriminate waste disposal and agricultural practices [12]. When nitrate in groundwater (as an equivalent of nitrogen e.g $\mathrm{NO}_{3}-\mathrm{N}$ ) is less than $0.2 \mathrm{mg} / \mathrm{L}$, it denotes natural or background level, 0.21-3.0 $\mathrm{mg} / \mathrm{L}$ represent a transition between natural and human influence and 3.1 $-10.0 \mathrm{mg} / \mathrm{L}$ are interpreted to indicate possible human influences [13]. The layout of most septic tanks and dugwells are not properly regulated in most cities of Nigeria, thus contamination from sewage is always possible. When groundwater is contaminated with sewage, most of the nitrogen is originally present in form of complex organic molecules which are eventually broken down by microbes to form nitrites and nitrates. In addition, nitrates can enter groundwater from chemical fertilizers used in agricultural areas. Excessive concentrations of nitrates and nitrites in drinking water pose an immediate and serious threat to infants under 3 months of age. The nitrates ions react with the blood haemoglobin, reducing the bloods ability to carry oxygen and this produces a disease called blue baby or methemoglobinemia [11]. The concentrations of the heavy metals were within the permissible values but the maximum values $(0.21$ $\mathrm{mg} / \mathrm{L}$ ) of $\mathrm{Pb}$ (wells no 4, 9 and 14) were higher than the $0.01 \mathrm{mg} / \mathrm{L}$ permissible limit. Lead is a commutative poison and a possible carcinogene. Excessive lead intake may cause the development of auto -immunity in which a person's immune systems attack its own cells which can lead to joint disease [14].

The concentration of $\mathrm{Fe}$ is high; a situation which has been reported in most groundwater in the basement complex of Nigeria [15]. Iron occurs naturally in soils and rocks because in most aquifers, groundwater comes in contact with this solid material, dissolving them. Usually iron is less than $0.5 \mathrm{mg} / \mathrm{L}$ in fully aerated water while groundwater with $\mathrm{pH}$ less than 8 can contains $10 \mathrm{mg} / \mathrm{L}$; infrequently, $50 \mathrm{mg} / \mathrm{L}$ may be present. Excess level in domestic water supplies are connected with staining of clothes and utensils, blackening of food and bitter taste, while overload in the body is linked to hemochromatosis, a genetic disorder which causes diabetes, impotence and liver failure [16].

The presence of microorganisms in groundwa- ter is heavily dependent upon geologic conditions such as flow pathways and mechanisms, sunlight, temperature, $\mathrm{pH}$, and soil properties. All the water samples showed growth (Table 5), suggesting that drinking the water may trigger any water borne diseases if not treated before consumption.

\subsection{Simulation}

This study utilized a multilayer perception (MLP) which has elements called neurons that are grouped into input, hidden and output layers with respective biases, weights and transfer functions. Figure 2 showed a summation $(\Sigma)$ and a nonlinear activation or transfer function (g). The common activation functions in use are the hyperbolic tangent (tanh) and sigmoid function [17]. The hyperbolic tangent (tanh) function is as shown in Eq. (1).

$$
\tanh (x)=\frac{1-\exp ^{-x}}{1+\exp ^{-x}}
$$

While the expressions for Tangent-Sigmoid (TanSig) and Log-Sigmoid transfer functions are shown in Eq. (2) and (3):

$$
\begin{gathered}
\operatorname{tansig}(x)=\frac{2}{1+\exp (-2 x)-1} \\
\operatorname{tansig}(x)=\frac{1}{1+\exp (-x)}
\end{gathered}
$$

The Tangent-Sigmoid (tansig) transfer function was used as the hidden layer while the linear transfer function-purling, was used at the output layer. Equation 4 gives the output of neuron, $i$, after the activation function,

$$
y_{i}=g_{i}=g\left(\sum_{j=1}^{k} w_{j i} x_{j}+\theta_{i}\right)
$$

The inputs to the neuron, $i$, are $x_{k}$, where $k=1, \ldots, K$. In this study, $x$ are the parameters (physico-chemical and heavy metals) and $w$ are the different weights assigned to each parameters by ANN. The inputs are multiplied by weights, $w_{k i}$ and are then summed up together with a bias term, $\theta_{i}$, which is a constant for each neuron. The ANN structure was trained in several rounds till satisfactory output was obtained with correlation value of $R^{2}=0.97$. The simulation procedure was tested in MATLAB and the program files were prepared to generate the goodness of fit parameters of the data points using correlation coefficients $\left(\mathrm{R}^{2}\right)$ and mean squared error (MSE) [17]. The mathematical expressions for the correlation coefficients and mean squared error (MSE) are shown in Eq. (5) and (6), respectively,

$$
R^{2}=1-\frac{\sum\left(Y_{\text {measured }}-Y_{\text {predicted }}\right)^{2}}{\sum\left(Y_{\text {measured }}-\frac{Y_{\text {predicted }}}{N}\right)^{2}}
$$




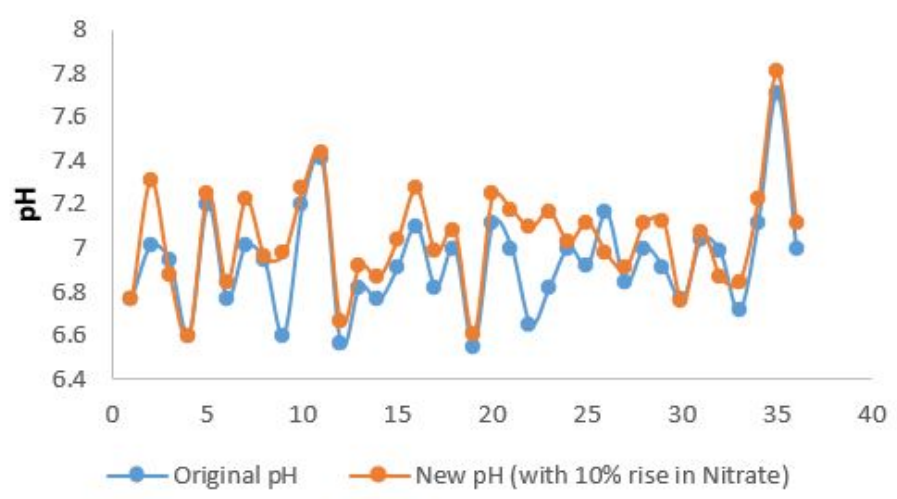

(a) Simulation of $\mathrm{pH}$ with $10 \%$ increase in nitrate

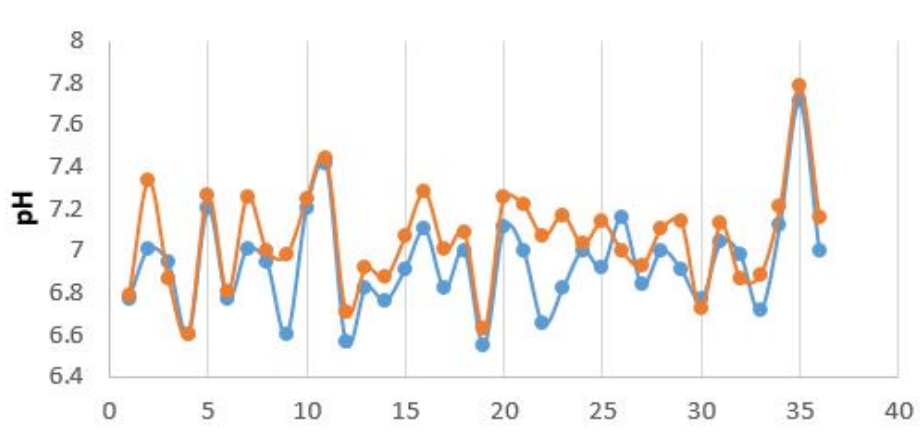

$\longrightarrow$ Original pH $\rightarrow \mathrm{New} \mathrm{pH}$ (with $10 \%$ rise in Bicarbonate)

(c) Simulation of $\mathrm{pH}$ with $10 \%$ increase in bicarbonate

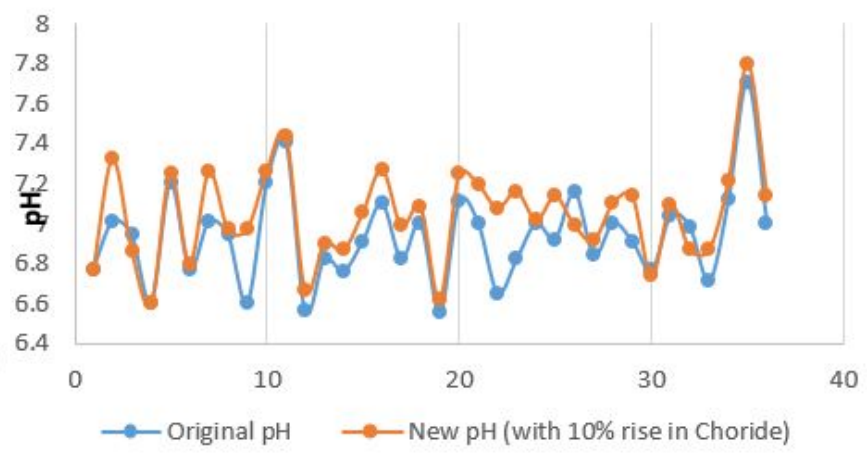

(b) Simulation of $\mathrm{pH}$ with $10 \%$ increase in chloride

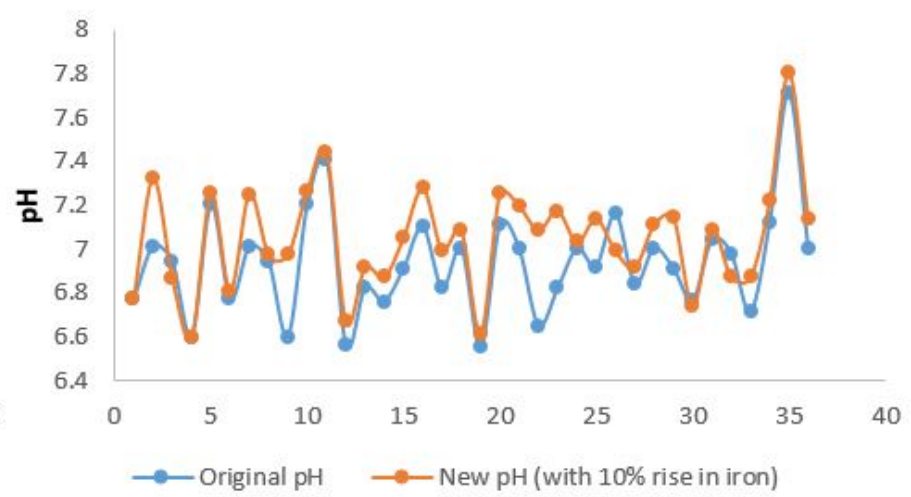

(d) Simulation of $\mathrm{pH}$ with $10 \%$ increase in iron

Figure 3: Simulation of $\mathrm{pH}$ with $10 \%$ increase in (a) nitrate, (b) chloride, (c) bicarbonate and (d) iron

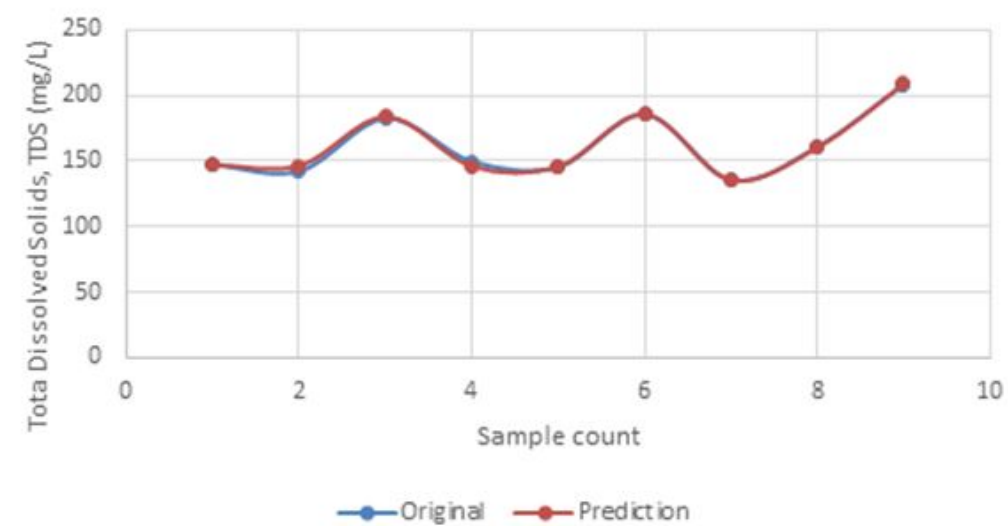

(a) Original and predicted TDS

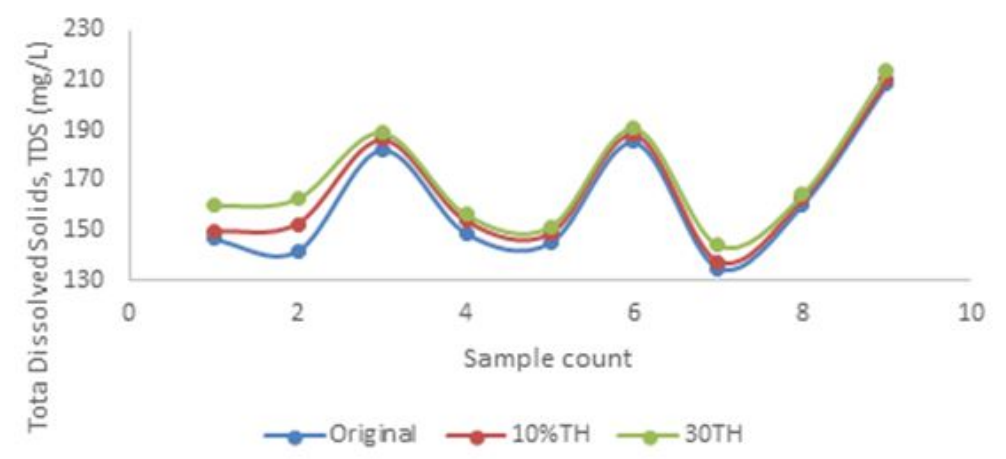

(b) Effect of total hardness on TDS

Figure 4: ANN prediction of TDS and effect on Total Hardness 


$$
\mathrm{MSE}=\frac{1}{\mathrm{~N}} \sum_{i=1}^{N}\left(Y_{\text {measured }}-Y_{\text {predicted }}\right)^{2}
$$

where $\mathrm{N}$ is the total number of data points predicted, $Y_{\text {measured }}$ is the observe parameter and $Y_{\text {predicted }}$ is the calculated parameter (output).

The result of the simulation (Fig. 3) revealed that at the $10 \%$ increase in the values of chloride, nitrate, iron, and lead, the $\mathrm{pH}$ value of the water increased. In addition, the ANN provides a good prediction of TDS values for all water samples and the TDS increased with increase percentage of total hardness (Fig. 4).

\section{CONCLUSION AND RECOMMENDATION}

Generally, the groundwater in the study area is good for drinking except for some wells that are polluted considering the concentrations of nitrates, nitrites and lead, thus, a routine monitoring of the wells is recommended to track the source of the pollutants. The users of the affected wells should be properly informed and appropriate treatment methods should be advised. The simulation of the $\mathrm{pH}$ using Artificial Neural Network (ANN) provides a good match at $10 \%$ increment of chloride, nitrate and iron and the acidity of the water sources reduced with the corresponding increase in the parameters. The model gave a good prediction of TDS for all the water samples considered.

\section{References}

[1] O. Fadipe, K. Oladepo, and J. Jeje, "Development Of A Groundwater Quality Map Of Ilesa West Local Government Area Osun State Nigeria-A GIS Approach," European Journal of Engineering and Technology, vol. 8, no. 1 , pp. 21-30, 2020.

[2] O. Adeyemi, O. B. Oloyede, and A. T. Oladiji, "Physicochemical and Microbial Characteristic of Leachate Contaminated Groundwater," Asian Journal of Biochemistry, vol. 2, no. 5, pp. 343-348, 2007.

[3] J. O. Jeje, O. R. Alo, and O. O. Fadipe, "Study On The Preparation And Testing Of Some Ferric Salts For Water Coagulation," European Journal Of Engineering And Technology, vol. 7, no. 6, pp. 50-56, 2019.

[4] P. Balakrishnan, A. Saleem, and N. D. Mallikarjun, "Groundwater Quality Mapping Using Geographic Information System (GIS): A Case Study of Gulbarga City Karnataka, India," African Journal of Science and Technology, vol. 5, no. 12, pp. 1069-1084, 2011.

[5] O. O. Fadipe, K. T. Oladepo, and J. O. Jeje, "Effect Of Land-Use On Groundwater Quality In Nigeria- A Case Study Of Ilesa West Local Government Area In Osun State," International Journal of Scientific And Engineering Research, vol. 10, no. 12, pp. 131-143, 2019.

[6] O. Gigilio, A. Quaranta, G. Barbuti, C. Napoli, G. Caggiano, and M. Montagna, "Factors influencing groundwater quality: Towards an integrated management approach," Annali Di Igiene Journals, vol. 27, pp. $52-57,2015$

[7] S. S. D. Foster, A. R. Lawrence, and B. M. Morris, "Groundwater in urban development," World Bank, Washington DC, U.S.A, World Bank Technical Paper, 1998, paper no 390.

[8] J. O. Jeje, "Effect of Water Supply Technologies on Sanitation Systems in Ife North Local Government Area of Osun State," Master's thesis, Obafemi Awolowo University, Ile-Ife, Nigeria, 2013.
[9] M. Ibraheem and B. Koch, "Assessment and Mapping of Groundwater vulnerability Using SAR Concentration and GIS : A Case Study in Al-Mafraq, Jordan," Journal of water resources and protection, vol. 7, pp. 588-596, 2015.

[10] A. O. Talabi and M. N. Tijani, "Assessment of Groundwater Quality in Parts of the Basement Complex Terrain of Southwestern Nigeria. Groundwater Quality Management in a Rapidly Changing World," in Proceedings 7th International Groundwater Quality Conference, Switzerland, 2011, pp. 503-506.

[11] J. A. Nathanson, Basic Environmental Technology. Washington D.C, U.S.A.: McGraw hill, 2000.

[12] A. Anilkuman, D. Sukumaran, and G. T. Vincent, S, "Effect of Municipal Solid Waste Leachate on Groundwater Quality of Thiruvananthapuram District, Kerela, India," Applied Ecology and Environmental Sciences, vol. 3, no. 5, pp. 151-157, 2015.

[13] R. T. Madison and J. O. Brunnet, "Overview of the occurrence of nitrate in groundwater of the united states u.s geological survey water supply," paper 2275 93-105, 1984 .

[14] V. Uwamariya, Adsorptive Removal of Heavy Metals from Groundwater By Iron Oxide Based Adsorbent. Balkema, Leiden, Netherlands.: CRC Press, 2013.

[15] O. O. Fadipe and K. T. Oladepo, "Temporal Variation of Groundwater Resources in Ilesa West Local Government, Osun State. Nigeria,"Nigerian Journal of Technology, vol. 39, no. 1, pp. 315-324, 2020.

[16] P. B. Andrew and J. F. Micheal, "Trace element analysis of iron, copper and zinc in skin," Department of Radiography, City University, Rutland Place, Charter House Square, London, U.K, 2000.

[17] L. K. Abidoye and D. B. Das, "Artificial neural etwork modeling of scale dependent dynamic capillary pressure effects in two-phase flow in porous media,"Journal of Hydroinformatics, vol. 17, no. 3, pp. 446-461, 2015. 